\title{
Evaluation of temporary flood-fighting structures
}

\author{
Johannes L. Wibowo ${ }^{1, a}$ and Donald L. Ward ${ }^{2}$ \\ ${ }^{1}$ U.S. Army Engineer Research and Development Center, Geotechnical and Structures Laboratory, 3909 Halls Ferry Rd. Vicksburg, MS \\ 39180, USA \\ ${ }^{2}$ U.S. Army Engineer Research and Development Center, Coastal and Hydraulics Laboratory, 3909 Halls Ferry Rd. Vicksburg, MS 39180, \\ USA
}

\begin{abstract}
Sandbags have traditionally been the product of choice for temporary, barrier-type, flood-fighting structures. However, sandbag structures are labor intensive and time consuming to construct and may not always be the best choice when selecting a flood-fighting barrier. To compare different barriers, the U.S. Army Engineer Research and Development Center (ERDC) developed a standard protocol to evaluate flood-fighting structures. Rapid Deployment Flood Wall (RDFW), Portadam, and Hesco Bastion were selected for testing based on technical merit from proposals submitted by companies that manufacture barrier-type, flood-fighting products. A standard sandbag structure was also tested.

The evaluation included time, ease, and cost of construction, performance under hydrostatic and wave loading, overtopping, debris impact, possible repair, reuse, environmental impact, and cost. The results of the evaluation showed that the RDFW performed well but is more expensive than the other structures and also not easy to disassemble. The Portadam was efficient under hydraulic loading but did not test well in the debris impact tests. The Hesco levee performed well except for the amount of seepage that was observed. The Hesco levee was later retested after the company improved the product, and much less seepage was observed during the retest. The sandbag levee failed during the overtopping test. These results provide the flood-fighting community with results that will assist in the selection of the product that best fits their need.
\end{abstract}

\section{Introduction}

Within the United States, sandbags have traditionally been the product of choice for temporary, barrier-type, flood-fighting structures. Sandbags are readily available and familiar to the general public. However, sandbag structures are labor intensive and time consuming to construct. In the 2004 Energy and Water Development bill, Congress recognized the need for expedient, temporary barrier-type, flood-fighting technology. In response to that need, the U.S. Army Engineer Research and Development Center (ERDC) developed a comprehensive laboratory and field testing program for the scientific evaluation of alternative floodfighting products [1].

Three commercially available flood-fighting products, Rapid Deployment Flood Wall (RDFW) [2], Portadam [3], Hesco Bastion Concertainers ${ }^{\circledR}$ [4], hereinafter referred to as Hesco, and sandbags were tested in a laboratory at Vicksburg, MS. RDFW consists of granular-filled, plastic grid units that connect together with both horizontal and vertical tabs to form a continuous structure. Each RDFW unit is $1.2-\mathrm{m}$-long by 1.2-m-wide by 0.2-m-high. Portadam consists of an impermeable membrane liner that is supported by a steel frame. Hesco are granular-filled, membrane-lined, wire baskets that are pinned together to form a continuous structure. Sandbags were tested because they are the standard temporary barrier type flood-fighting product used by the U.S. Army Corps of Engineers (USACE).

\section{Testing protocol}

The Standard Testing Protocol (STP) was developed at ERCD to test flood-fighting structures. The STP requires that an engineering-based study must have been performed previously on the structure to establish structural stability, with calculations presented for water pressure at all elevations up to $100 \%$ of the product height, and the product must have previously completed manufacturers' testing.

The protocol for the laboratory testing included both performance parameters (hydrostatic testing, hydrodynamic testing with waves and overtopping, and debris impact) and laboratory setting operational parameters (time, manpower, and equipment to construct and disassemble, suitability for construction and disassembly by unskilled labor, fill requirements, ability to construct around corners, disposal of fill material, damage, repair, and reusability).

\footnotetext{
a Corresponding author: Johannes.L.Wibowo@usace.army.mil
} 
For the hydrostatic test, the pool elevation in front of the levee was raised to three different elevations, $33 \%$, $66 \%$, and $95 \%$ of levee height, for a minimum of $22 \mathrm{hr}$ at pool elevations of $0.3 \mathrm{~m}$ and $0.6 \mathrm{~m}$ to ensure hydrostatic comparability regardless of levee height. During the testing period, levee movement and seepage values were recorded. During and after each test, the levee was inspected for weakness and/or failure before the pool elevation is raised to the next level. The hydrodynamic test includes $66 \%$ and $80 \%$ of the levee height using low, medium-, and high-waves. Overtopping was achieved from $2.5 \mathrm{~cm}$ of overflow during a $1-\mathrm{hr}$ time period. The layout of the testing structures is shown in Figure 1, and the testing matrix is presented in Table 1.

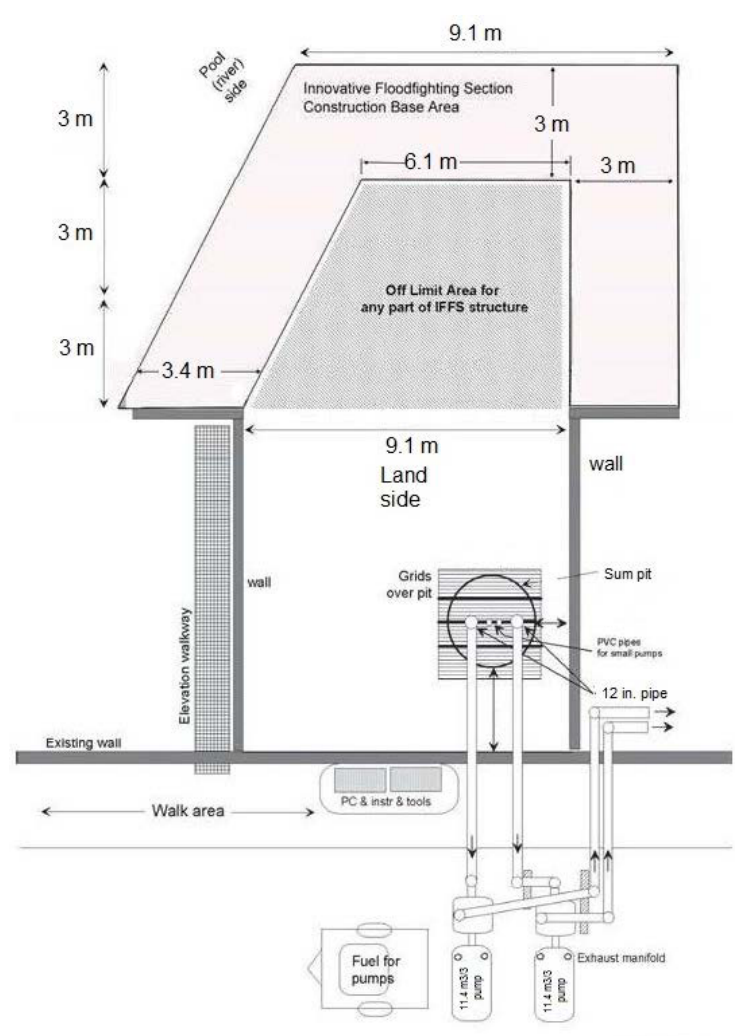

Figure 1. Layout of test plan [1].

\begin{tabular}{|c|c|c|}
\hline Test & Pool/Test Condition & Repair Allowed \\
\hline \multirow{3}{*}{ Hydrostatic } & $33 \% \mathrm{H}, 22$ hour & After 22 hour test \\
\hline & $66 \% \mathrm{H}, 22$ hour & After 22 hour test \\
\hline & $95 \% \mathrm{H}, 22$ hour & $\begin{array}{c}\text { After } 22 \text { hour test, and water } \\
\text { level lowered to } 66 \% \mathrm{H}\end{array}$ \\
\hline \multirow{6}{*}{ Hydrodynamic } & $\begin{array}{c}66 \% \mathrm{H} \text {, Low-wave, } \\
7 \text { hour }\end{array}$ & After finish of 7 hour \\
\hline & $\begin{array}{c}66 \% \mathrm{H}, \mathrm{Med}-\text { wave, } \\
3 \times 10 \mathrm{~min}\end{array}$ & \multirow{2}{*}{$\begin{array}{c}\text { After finish of } 66 \% \mathrm{H}, \\
\text { High-wave test }\end{array}$} \\
\hline & $\begin{array}{c}66 \% \mathrm{H} \text {, High-wave, } \\
3 \times 10 \mathrm{~min} \\
\end{array}$ & \\
\hline & $\begin{array}{c}80 \% \mathrm{H} \text {, Low-wave, } \\
7 \text { hour }\end{array}$ & After finish of 7 hour \\
\hline & $\begin{array}{c}80 \% \mathrm{H}, \text { Med-wave, } \\
3 \times 10 \mathrm{~min}\end{array}$ & \multirow{2}{*}{$\begin{array}{c}\text { After finish of } 80 \% \mathrm{H} \text {, } \\
\text { High-wave test }\end{array}$} \\
\hline & $\begin{array}{c}80 \% \mathrm{H}, \text { High-wave, } \\
3 \times 10 \mathrm{~min} \\
\end{array}$ & \\
\hline Overtopping & $\begin{array}{c}2.5 \mathrm{~cm} \text { overflow, } \\
1 \text { hour }\end{array}$ & Major repair or rebuild \\
\hline \multirow[t]{2}{*}{ Impact Debris } & $0.3 \mathrm{~m} \mathrm{log}, 8 \mathrm{~km} /$ hour & \multirow[t]{2}{*}{ Removal of all material } \\
\hline & $0.4 \mathrm{~m} \log , 8 \mathrm{~km} / \mathrm{hour}$ & \\
\hline
\end{tabular}

Table 1. Testing Matrix [1].

\section{Description of flood fighting structures}

Laboratory testing of Portadam, Hesco, RDFW, and sandbag structures was conducted in a wave research basin at ERDC. The products were tested in a controlled laboratory setting but under conditions that emulate realworld flood fighting. The structures were tested consecutively under identical conditions.

ERDC defined the dimensions for the structures (Figure 1), but each company was responsible for the construction and disassembling of their product. The laboratory testing included the construction of skewed $\mathrm{u}$-shaped structures. The length of the structures varied from approximately $21 \mathrm{~m}$ to about $24.7 \mathrm{~m}$. Due to the restrictive height of the research basin walls, the height of each structure was limited to approximately $0.9 \mathrm{~m}$. The sandbag structure was tested first followed, in order, by Hesco, RDFW, and Portadam.

\subsection{Sandbag levee}

In this experiment, the sandbag levee was constructed following the protocol used by the USACE Seattle District. The protocol requires that sandbags be filled to two-thirds full and that the bags occupy a space of 0.25 -m-wide by $0.3-\mathrm{m}$-long by $0.1-\mathrm{m}$-high. The weight of a bag filled two-thirds full is determined by the density of the fill material. The as-built cross-section of the levee structure is shown in Figure 2. The sand used in this experiment is locally available sand classified as a poorly-graded sand (SP) with the gradation curve depicted in Figure 3. There are various companies that sell mechanical sandbag fillers and others that sell readyfilled sandbags. In this project, the sandbags were filled with a sandbag-filling machine manufactured by Hogan Manufacturing Company. The Hogan machine uses a fixed volume auger and produces sandbags with constant volume (Figure 4).

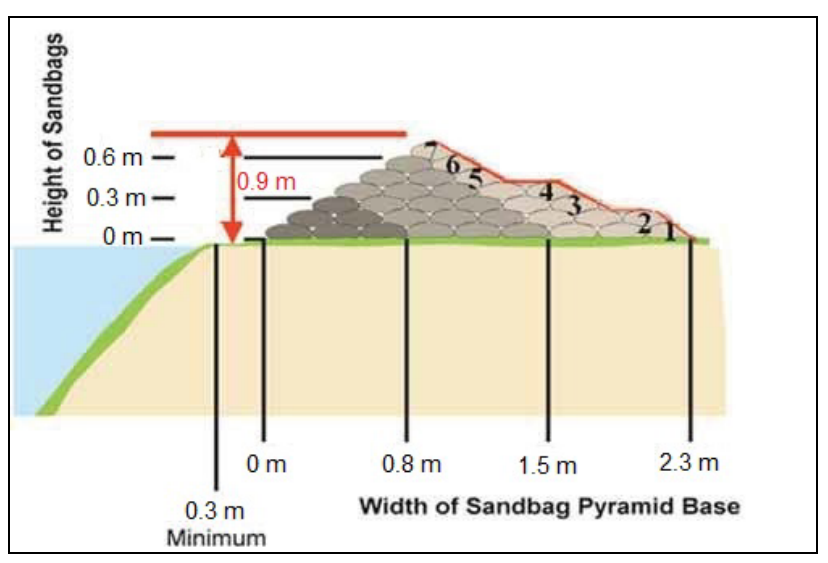

Figure 2. As-built sandbag levee.

The sandbag levee was constructed using manual labor (Figure 5) and a front loader to bring the filled sandbag close to the constructed levee. The time needed for sandbag levee construction and the number of labor hours required to construct the levee were recorded. The sandbag levee was then ready for tests following the testing protocol (Figure 6). 


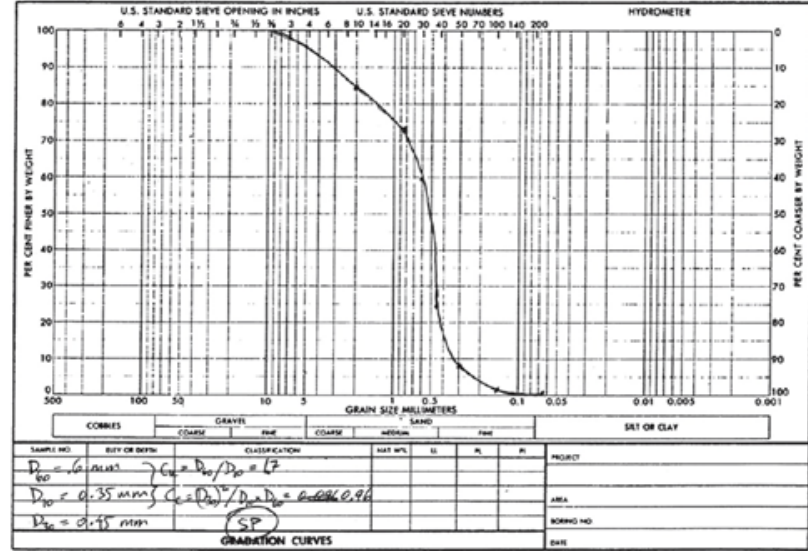

Figure 3. Grain size of sand (SP) used for sandbags.

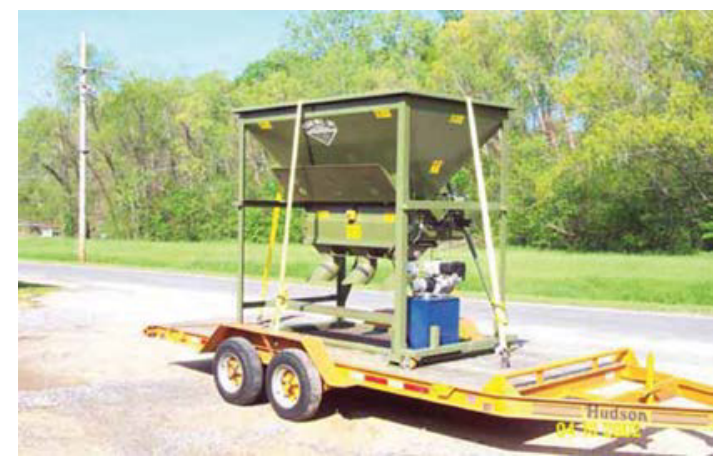

Figure 4. Sandbag machine, Hogan Manufacture Inc.

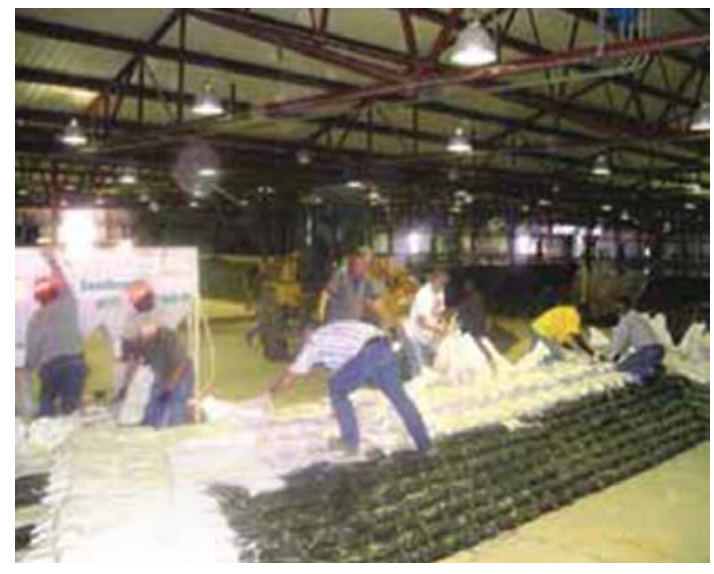

Figure 5. Sandbag levee construction.

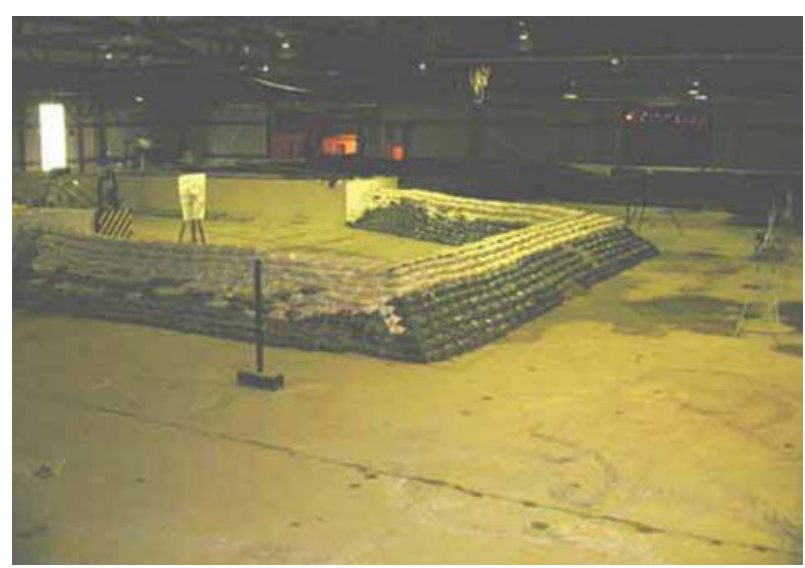

Figure 6. Sandbag levee ready for test.

\subsection{Hesco Bastion}

Hesco is listed under U.S. Patents 3333970, 5472297 and European Patent 046626 and is a structural system of linked baskets containing fill material. Hesco systems have been used around the world for military operations as well as for resolving natural disasters [4]. The units (Figures 7-8) are manufactured in various sizes and are made of welded galvanized-steel mesh that is assembled with coiled joints. A polypropylene nonwoven, geotextile liner retains the fill material (sand, gravel, or other fill) that is dumped into the open (top and bottom) basket using minimal labor and commonly available equipment. The baskets are flat-packed on pallets, extended and joined with joining pins, filled with fill material, and stacked in various configurations depending on the end-use. The units are lightweight, portable, and are easily handled. For the ERDC tests, the Hesco Flood Unit system (General Services Administration (GSA) No. GS-07F5369P) was furnished by the company with unfolded unit dimensions of 0.9-mhigh by 0.9 -m-depth by 3.7-m-long, and commercial price of $\$ 295$ per unit (approximately $\$ 80$ per linear meter $)$. End panels $(0.9 \mathrm{~m} \times 0.9 \mathrm{~m} \times 0.9 \mathrm{~m})$, connecting joining pins $(0.9 \mathrm{~m})$, and connecting coil hinges $(0.9 \mathrm{~m})$ were also furnished. The wire mesh, joining pins, and coil hinges were manufactured from 8-gauge steel and coated with a proprietary galvanizing. The size of the wire mesh opening was $7.6 \mathrm{~cm}$ by $7.6 \mathrm{~cm}$. The nonwoven, geotextile liner was Geotex 641. Figure 7 shows the process of assembling the unit and the filling with dry sand. In Figure 8, the Hesco levee is ready for tests.

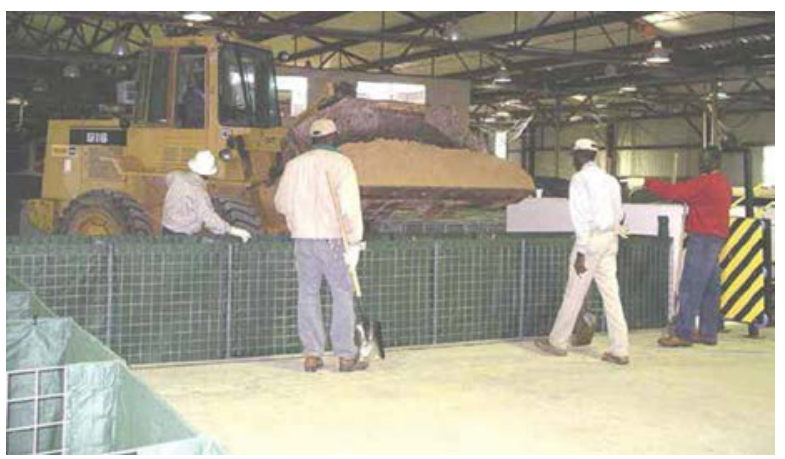

Figure 7. Filling the Hesco Bastion levee with sand.

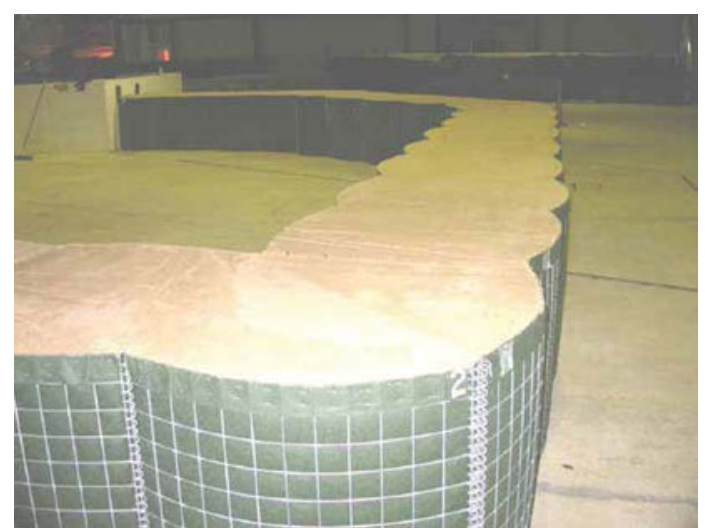

Figure 8. Hesco levee ready for test. 


\subsection{Rapid Deployment Flood Wall (RDFW)}

The RDFW was originally developed from the concept of expandable plastic grid system ("sand grid"), which was invented at ERDC in the 1980s (U.S. Patent 4,797,026). The original RDFW proponents licensed the sand grid patent from USACE and developed a refined version of the technology, which was later researched at ERDC with a Cooperative Research and Development Agreement (CRADA) in 1996.

The RDFW system is commercially available through the Geocell Systems Corporation (http://www.geocellsystems.com) and is also sold through the GSA procurement schedule \#GS-07F$0340 \mathrm{M}$, with a unit price of $\$ 100$ [2]. Each unit is a modular, lightweight, and collapsible plastic grid that allows for several stacking configurations and connections. The unit is shipped in a box. The plastic material is a polyester polymer manufactured by Eastman Inc. (EastarTM copolyester 5445). The 1.2-m-deep by 1.2 -m-long by $0.2-\mathrm{m}$-high grid units are laid side-by-side and interlocked. Vertical stacking allows additional height capacity. Once the desired grid geometry is achieved, the grid units are filled with sand. The sand achieves compressive strength and provides the mass to resist sliding forces and overturning moments. The sand used in this experiment was the same used for the other levee structures, with a soil classification of poorlygraded (SP) sand.

Figure 9 and Figure 10 show the assembling process of RDFW unit and the filling with sand, respectively. The filling process using a front loader was followed by taping process to ensure that all of the units were filled with sand. Once these steps were completed, the RDFW levee was ready to be tested as shown in Figure 11.

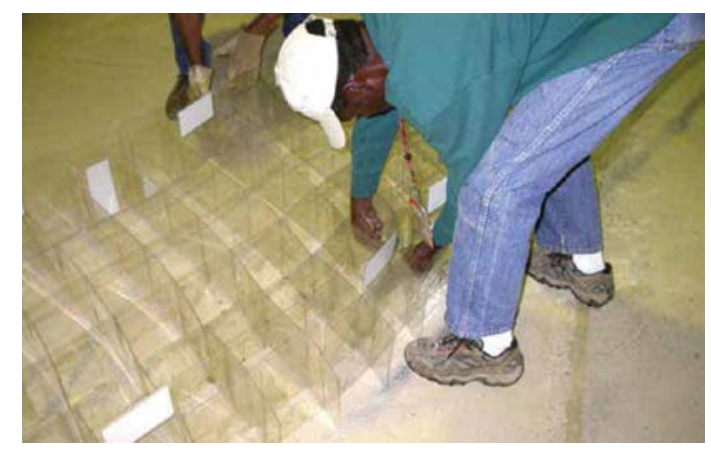

Figure 9. Start assembling RDFW levee.

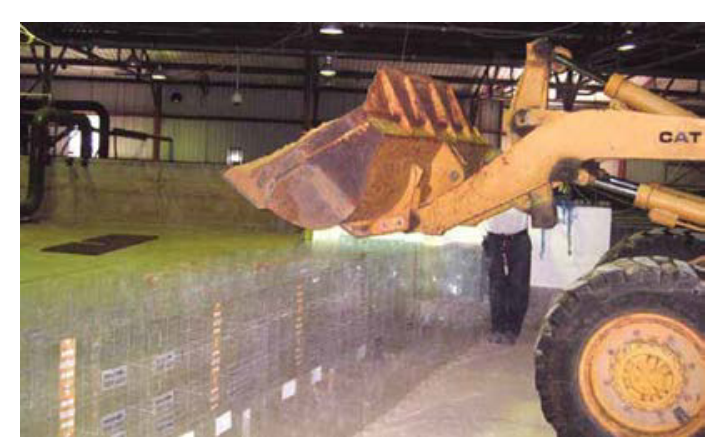

Figure 10. Filling the RDFW levee with sand.

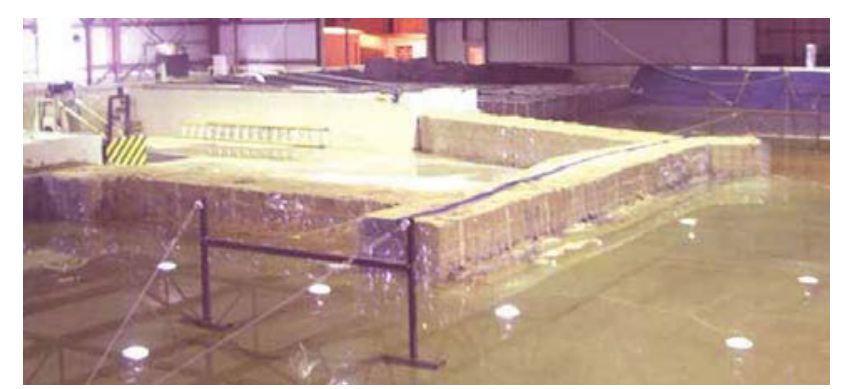

Figure 11. RDFW levee ready for test.

\subsection{Portadam}

The Portadam $\AA$ company specializes in both waterdiversion and cofferdam structures [3]. The system is a steel framework supporting a vinyl liner, which acts as a dam to prevent floodwater damage inside the area protected by the structure. No fill materials are required, but sandbags are typically used to weigh down the liner's bottom edge (the apron). The top edge of the liner is tied to the steel frame.

The steel framework and vinyl liner are manufactured in various lengths and sizes depending on the application. The system provided for this test consisted of a frame $1.5-\mathrm{m}$-high with $1.5-\mathrm{m}$-base width and a vinyl-coated polyester tarp $(610 \mathrm{~g} / \mathrm{sqm}$ Style 3818 manufactured by Seaman, Incorporated). The tarp extended from lying flat on the floor in front of the frame up to and attached to the front face of the frame at a height of $0.9 \mathrm{~m}$ for this test. For the ERDC test, the $1.5-\mathrm{m}$ steel frames, a roll of vinyl tarp, and a barrel of connectors were furnished by the company. Commercial price to purchase the materials was listed as approximately \$203 (U.S. dollars) per linear meter.

Figure 12 and Figure 13 show the construction of the Portadam levee. Figure 14 is the completed structure to be tested.

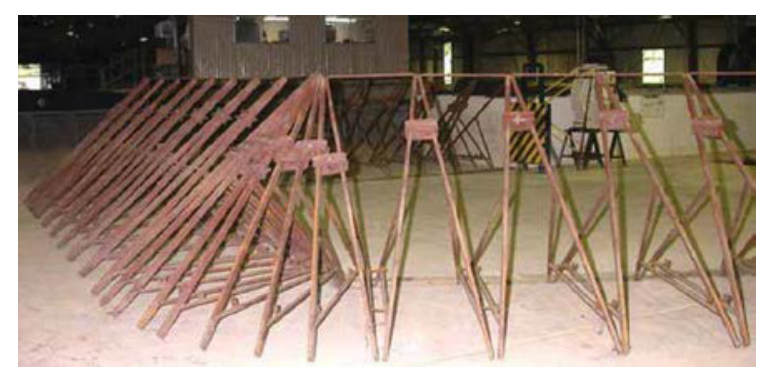

Figure 12. Construction of the Portadam steel structures.

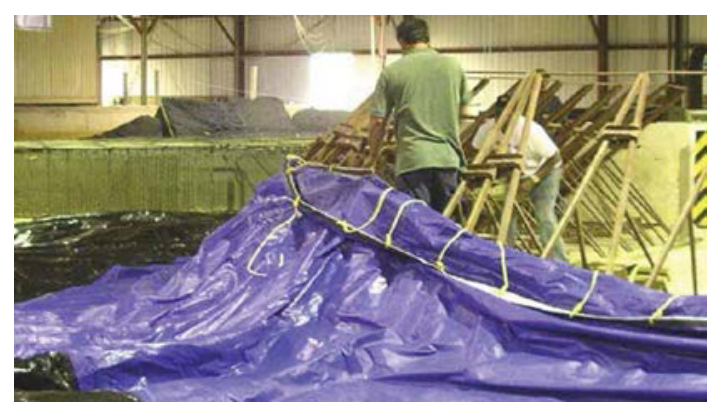

Figure 13. Installing the tarp on the steel structures. 


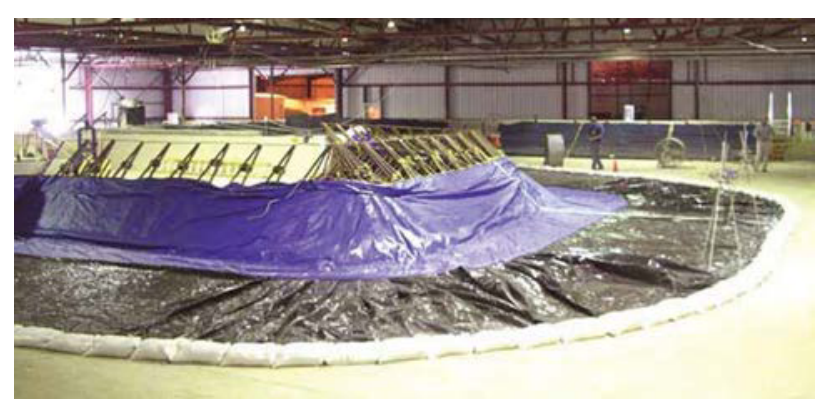

Figure 14. Portadam levee ready for test.

\section{Observations and Test Results}

This section summarizes the observations and test results of the four flood-fighting structures following the testing protocol described in Section 2. Both the positive and negative responses were recorded.

\subsection{Sandbags}

In general, sandbag levees are easy to build, but a person with basic knowledge of sandbag levees should be present during construction to provide guidance. Burlap bags should be staged in close proximity to the area where flooding is imminent. Filler material, preferably dry sand, is usually available from a nearby source. A front loader and a sandbag machine can be used to decrease the time of construction, although bags can be filled manually using shovels. The time needed to build a 25-m-long levee is 11.5 hours with a total effort of approximately 200 man-hours (about 17 people). The seepage of the sandbag levee under $95 \%$ of the maximum levee height under hydrostatic loading of about 22 hours is shown in Figure 15. The highest seepage rate occurred during the first four hours of the test, up to 8.7 liter/min per linear meter of the levee. The seepage force rearranges the sand packing causing the levee to become less permeable. The seepage becomes stable at a seepage rate of 6 liter/min per linear meter of the sandbag levee.

During hydrodynamic loading, minor damage occurred on the water side. Under $2.5 \mathrm{~cm}$ overtopping, the sandbag levee failed (Figure 16). Figure 17 shows the progress of breaching as the sandbag levee by observing the seepage rate progression. The levee starts overtopping after 12 minutes of testing. After 28 minutes, the sandbag levee starts to partially breach and, at 36 minutes, the sandbag levee was fully breached (Figure 9). In this sandbag levee overtopping test, the breach initiation time is 16 minutes, and the breach formation time is 14 minutes.

The sandbag levee was very resistant against debris impact loading. The sandbag is non-re-useable; however, the bags are made of biodegradable material.

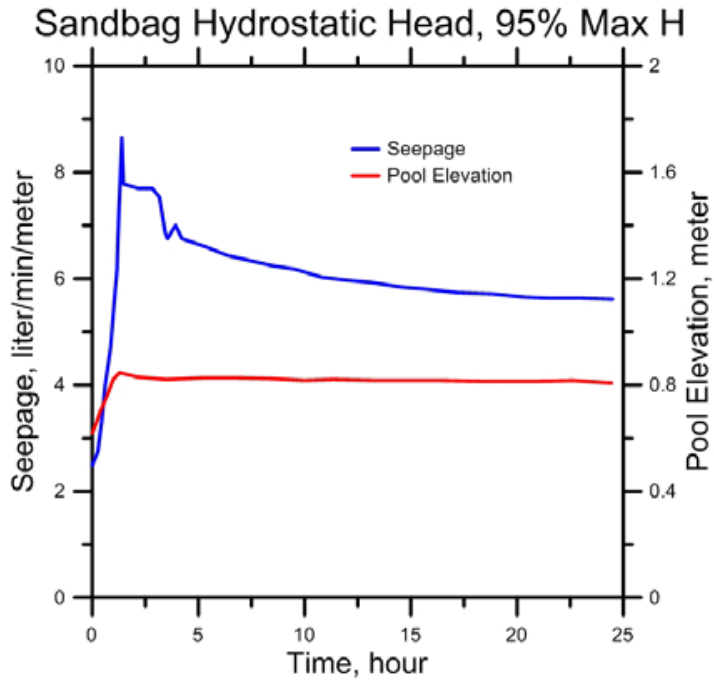

Figure 15 Seepage of sandbag levee under $95 \%$ of maximum high hydrostatic loading.

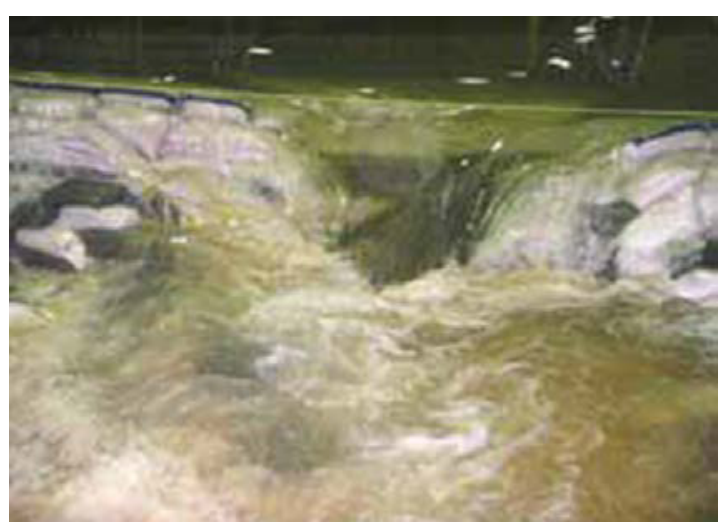

Figure 16. Sandbag levee overtopping.

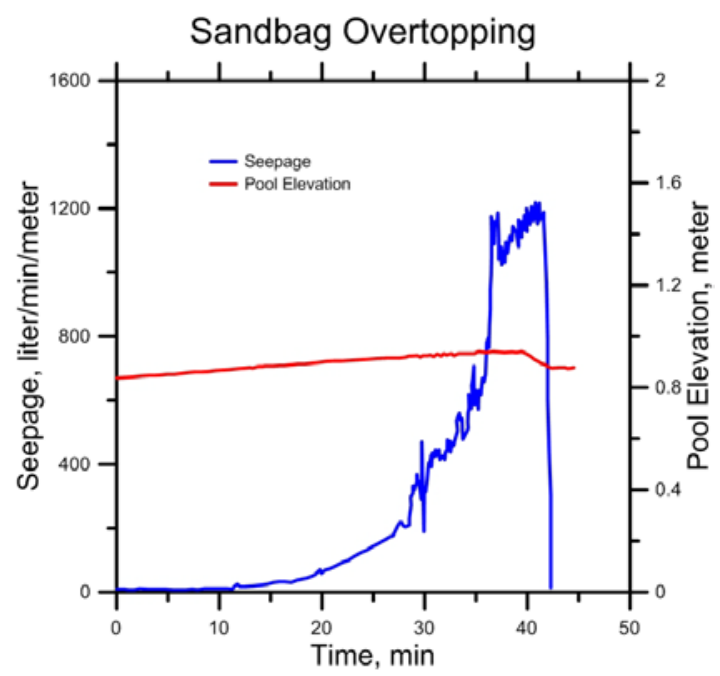

Figure 17. Seepage of sandbag levee during overtopping. 


\subsection{Hesco}

The Hesco levee is relatively easy to build. The wire mesh with the fabric can be assembled quickly and filled with sand, gravel or other fill material using a front loader. The Hesco unit should be readily available in flood-prone areas during flood season. A source for the fill material can usually be found near the area where the Hesco levee is needed. During construction, someone with a basic knowledge of a Hesco levee should be available on-site to provide instruction. The construction time to build a $25-\mathrm{m}$-long levee is 3.5 hours with total efforts of 21 man hours ( 6 people). During the hydrostatic loading tests, the Hesco levee shows a large quantity of seepage, up to $22.5 \mathrm{liter} / \mathrm{min}$ per linear meter of levee. Seepage occurred through the vertical space between the two connected units. Figure 18 shows that the seepage per unit of Hesco levee length was more than twice than that of the seepage observed during the test of the sandbag levee. Hesco has improved the use of the fabric for the unit. ERDC retested the Hesco unit after the company improved the flood-fighting unit in 2014 [5]. Under the same test loading, the maximum seepage rate was 1.24 liter/min per meter length of levee.

During hydrodynamic loading, overtopping (Figure 19), and debris impact, the Hesco levee performed well with no damage observed during the tests. The disassemble process is relative easy, and $100 \%$ of the unit can be reused. The Hesco does not have any negative impact in environmental aspect.

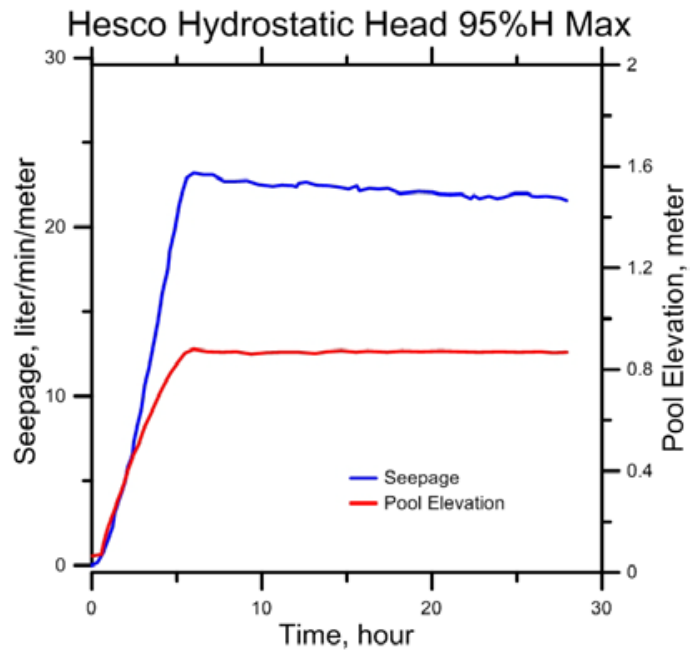

Figure 18. Seepage of the Hesco levee under hydrostatic loading of $95 \%$ of maximum levee height.

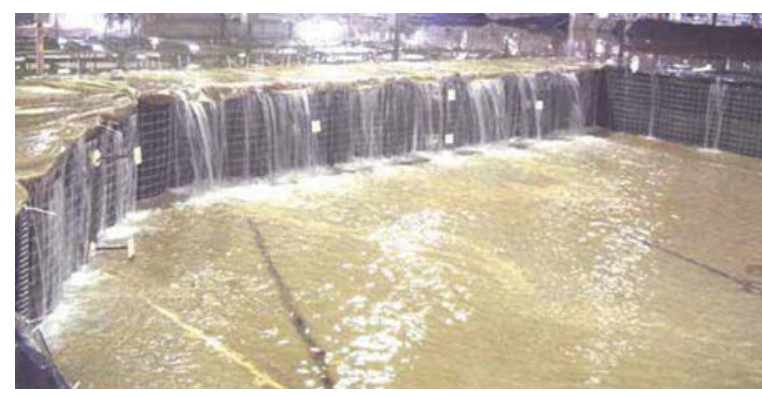

Figure 19. Hesco levee overtopping.

\subsection{RDFW}

The RDFW is also easy to construct, although not as easy as Hesco. The unit can be assembled quickly and filled with preferably dry sand using front loader or manually using shovels. The RDFW needs to be available during flood season. The preferred fill material is dry sand. The construction time to build a $25-\mathrm{m}$-long levee is 5.5 hours with total efforts of 33 man hours (6 people). In terms of seepage, the RDFW performed the best among the tested flood-barriers. Under $95 \%$ of maximum height hydrostatic loading, the RDFW levee experience only maximum 1.2 liter/min per meter length of levee. The compartment of the grid system of the RDFW unit causes the sand may not fill every corner of the grid. This may affects the initial porosity of the unit to be high. During the initial filling time, the sand material rearranges itself to the grain-packing pattern. Figure 20 shows the subsidence in RDFW unit after the initial filling. Figure 21 shows that the seepage is high during the first hour of the test. The seepage gradually reaches an equilibrium value of about 1.0 liter/min per meter length of the levee. During hydrostatic, hydrodynamic loading, overtopping, and debris impact, the RDFW levee performed very well. The disassembling process is not easy; only $90 \%$ of the unit is recoverable. The RDFW does not have any negative impact on the environment.

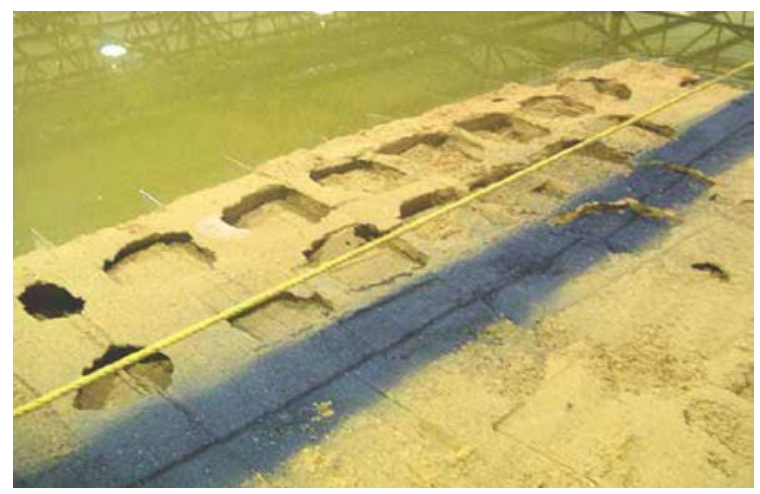

Figure 20. Sand subsidence on RDFW levee.

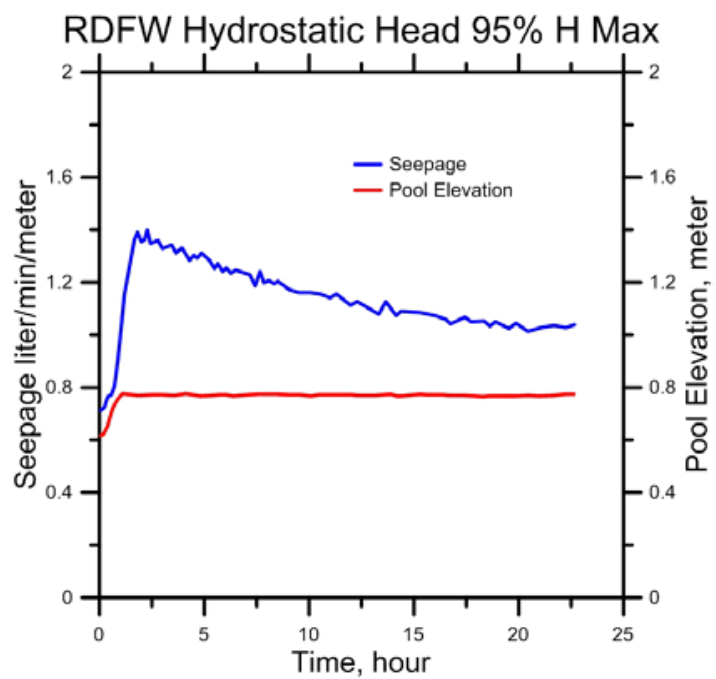

Figure 21. Seepage of RDFW levee under hydrostatic loading of $95 \%$ of maximum levee height. 


\subsection{Portadam}

The Portadam levee is also relatively easy to build. The frame needs to be assembled using rachet and socket by someone with basic knowledge of the Portadam unit. A front loader will help to transport the Portadam steel frame. The Portadam unit, steel frame, and a tarp should be available during the flood season. Sandbags (10 bags per meter length of the levee) are needed for keeping the tarp in place. The construction time to build a $25-\mathrm{m}-$ long levee is 4.8 hours with total efforts of 24 man hours (5-6 people). In terms of seepage, the Portadam perform well compared with the other tested flood-barriers. Figure 22 shows under $95 \%$ of maximum height, the maximum seepage is 1.7 liter/min per meter length of levee. The seepage during overtopping is quite high the tip of the tarp sagged during overtopping. During hydrostatic, hydrodynamic loading (Figure 23), the Portadam levee performed very well. The weakness of this system is debris impact loading as shown in Figure 24 and Figure 25. The tarp was torn during the debris impact test. The disassembling process is quite easy; $100 \%$ of the unit recovered. The Portadam does not have any negative impact on the environment.

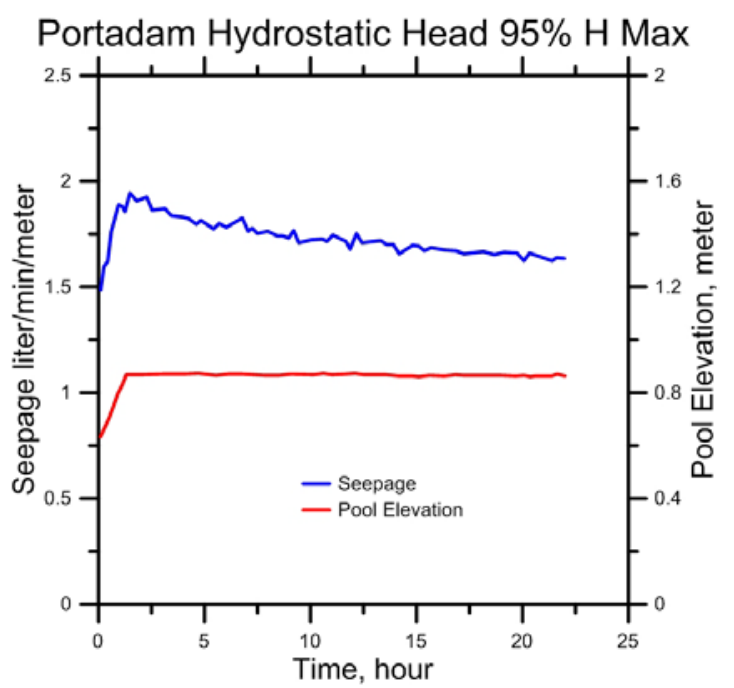

Figure 22. Seepage of Portadam levee under hydrostatic loading of $95 \%$ of maximum levee height.

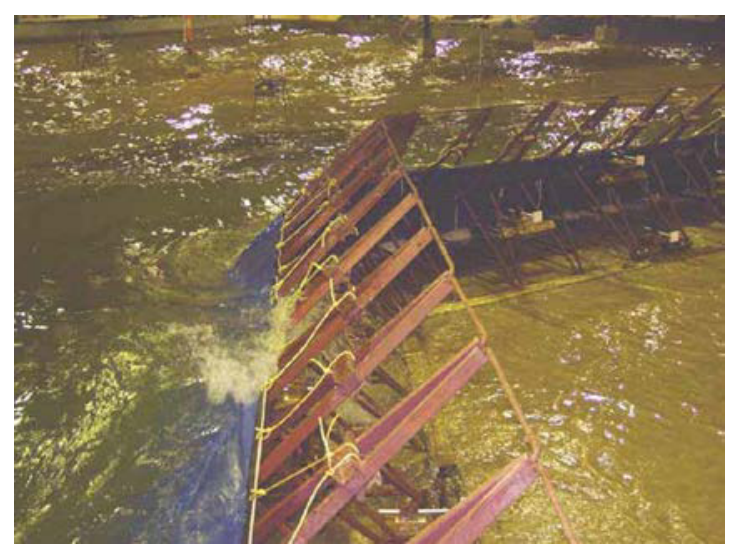

Figure 23. Portadam levee under high wave loading.

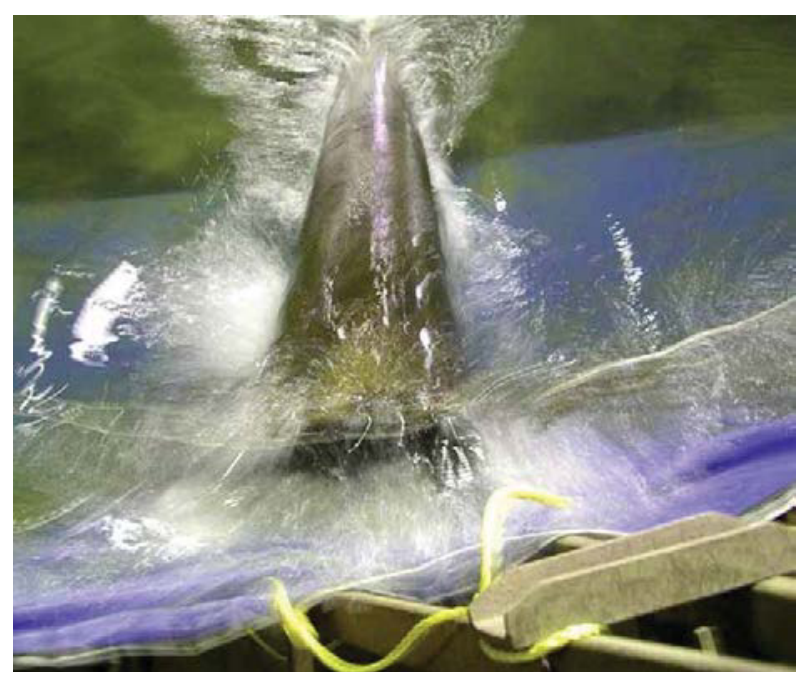

Figure 24. Portadam levee under debris impact loading.

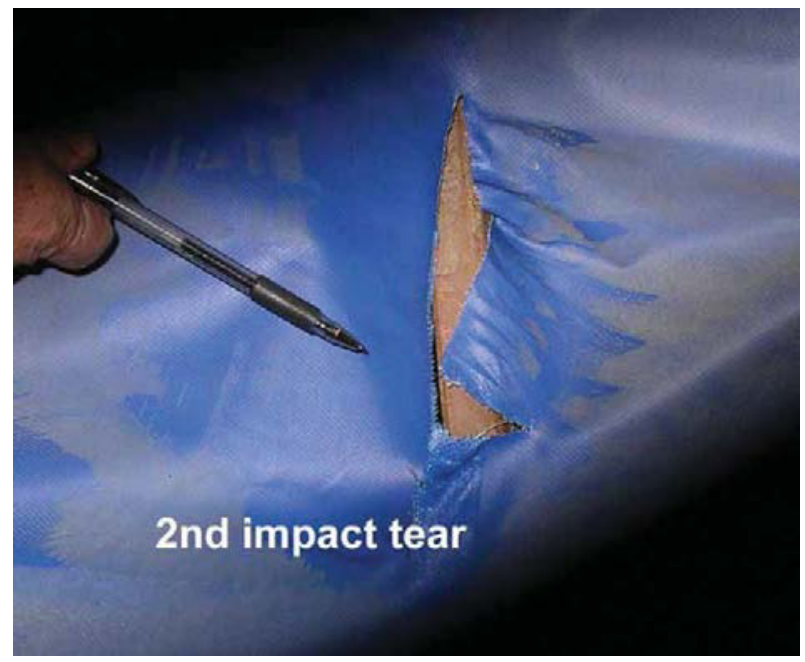

Figure 25. Portadam after impact loadings.

The complete test results of the four flood-fighting barrier can be found in Table 2 and Table 3, as well as in the report by Pinkard et al. [1]

\section{CONCLUSIONS}

Four flood fighting structures system were tested following a STP developed by ERDC. The four structures were sandbag, Hesco, RDFW, and Portadam. The evaluation included time, ease, and cost of construction, performance under hydrostatic and wave loading, overtopping, debris impact, possible repair, reuse, environmental impact, and cost. The results of the evaluation showed that the RDFW performed well but is more expensive than the other structures and also not easy to re-assemble. The Portadam was efficient under hydraulic loading but did not test well in the debris impact tests. The Hesco levee performed well except for the amount of seepage that was observed. The Hesco levee was later retested after the company improved the product, and no seepage was observed during the retest. Only the sandbag levee breached during the test. The breach initiation time and breach formation time were observed through the seepage pattern during overtopping. 
These results provide the flood-fighting community with results that will assist in the selection of the product that best fits their temporary, barrier-type, flood-fighting requirements.

\section{ACKNOWLEDGEMENT}

The authors acknowledge the U.S. Army Corps of Engineers, Headquarters, for the funding and opportunity to perform this study and to the U.S. Army Corps of Engineers, Vicksburg District, for the sandbag levee materials.

\section{REFERENCES}

1. Pinkard, F., T. Pratt, D.L. Ward, T. Holmes, J. Kelley, L.T. Lee, G. Sills, E. Smith, P.A. Taylor, N. Torres,
L. Wakeley, J.L. Wibowo. 2007. Flood-Fighting Structures Demonstration and Evaluation Program: Laboratory and Field Testing in Vicksburg, Mississippi. Technical Report ERDC TR-07-3.

2. Geocell. 2004. http://www.geocellsystems.com.

3. Portadam. 2004. http://www.portadam.com.

4. Hesco. 2004. http://www.hesco-usa.com.

5. Ward, D.L. 2014. Evaluation of Hesco Bastion Concertainer SL3636 Flood Fighting Barrier. ERDC Report to Sponsor. U.S. Army Corps of Engineers ERDC, Vicksburg. 


\begin{tabular}{|c|c|c|}
\hline \multicolumn{3}{|l|}{ Laboratory Test Summary } \\
\hline Item & Sandbags & RDFW \\
\hline $\begin{array}{l}\text { ROW used }(m) \\
\text { Restricted by the facility size only }\end{array}$ & $n / a$ & $n / a$ \\
\hline Footprint Width $(\mathrm{m})$ & 3 & 1.8 \\
\hline Apron Width (m) & $n / a$ & $\mathrm{n} / \mathrm{a}$ \\
\hline \multicolumn{3}{|l|}{ Structure Length $(\mathrm{m})$} \\
\hline Center-line Len. (m) & 24.6 & 22.4 \\
\hline \multicolumn{3}{|l|}{ Ease of Construction } \\
\hline Time (hr) & 11.5 & 5.5 \\
\hline Effort (man-hours) & 205.1 & 32.8 \\
\hline Manpower (no. men) & $17+2$ part time & 6 \\
\hline Equipment & $\begin{array}{l}\text { Sandbagger Shovels } \\
\text { Bobcat }\end{array}$ & \begin{tabular}{|l|} 
Shovels \\
2 Bobcat Loaders
\end{tabular} \\
\hline Sand Fill $\left(\mathrm{M}^{3}\right)$ & 40.0 & 26.8 \\
\hline Durability & \multicolumn{2}{|c|}{$\begin{array}{l}\text { All products stayed in the laboratory during construction and testing with no direct sunlight and } \\
\text { subjected only to the ambient temperature of the steel building. No deterioration was noted. }\end{array}$} \\
\hline Varying Terrain & \multicolumn{2}{|c|}{$\begin{array}{l}\text { The laboratory test products were all built on a flat surface (finished concrete floor) along the entire } \\
\text { length of the structures. }\end{array}$} \\
\hline \multicolumn{3}{|l|}{ Ease of Removal } \\
\hline Time (hr) & 4.5 & 7 \\
\hline Effort (man-hours) & 9 & 42 \\
\hline Manpower (no. men) & 2 & 6 \\
\hline Equipment & $\begin{array}{l}916 \mathrm{Cat}^{\odot} \text { Front End } \\
\text { Loader } \\
\text { Broom and Shovel }\end{array}$ & $\begin{array}{l}2 \text { Shop Vacuums } \\
2 \text { Sharp Shooter Shovels } 3 \text { Small Folding Shovels Bobcat }\end{array}$ \\
\hline Seepage-Hydrostatic Head Test & \multicolumn{2}{|r|}{ Seepage (Liter per Minute per Meter of Structure) } \\
\hline $0.3 \mathrm{M}$ water elev. & 0.583 & 0.261 \\
\hline $0.6 \mathrm{M}$ water elev. & 2.856 & 0.944 \\
\hline 90 and $95 \%$ structure height & 6.0 & 1.192 \\
\hline $\begin{array}{l}\text { Seepage - Dynamic Tests } 66 \% \\
\text { Structure height water elevation }\end{array}$ & \multicolumn{2}{|r|}{ Seepage (liter per minute per meter of Structure) } \\
\hline $5 \mathrm{~cm}$ wave height & 3.229 & 0.472 \\
\hline $17.8 \mathrm{~cm}$ wave height & 3.415 & 0.522 \\
\hline 27.9 wave height & 38.375 & 4.471 \\
\hline $\begin{array}{l}\text { Seepage - Dynamic Tests } 80 \% \\
\text { Structure height water elevation }\end{array}$ & \multicolumn{2}{|r|}{ Seepage (liter per minute per meter of Structure) } \\
\hline $5 \mathrm{~cm}$ wave height & 4.844 & 0.534 \\
\hline $17.8 \mathrm{~cm}$ wave height & 92.151 & 55.639 \\
\hline $27.9 \mathrm{~cm}$ wave height & 217.59 & 109.91 \\
\hline \multirow[t]{2}{*}{ Overtopping } & \multicolumn{2}{|r|}{ Maximum Flow Over Structure + Seepage $\left(\mathrm{M}^{3} /\right.$ Minute $)$} \\
\hline & $\begin{array}{l}\text { Undulating elevation along } \\
\text { structure } 29.41\end{array}$ & $\begin{array}{l}\sim \text { Constant elevation along structure } \\
9.1\end{array}$ \\
\hline Damage - Overtopping & $\begin{array}{l}\text { Failed } \\
>5 \text { min. into test }\end{array}$ & No damage Tested 1 hour \\
\hline Damage - Log Impact & No Damage & No Damage \\
\hline $\begin{array}{l}\text { Structural Damage } \\
\text { During Installation, Testing, and } \\
\text { Removal }\end{array}$ & $\begin{array}{l}\text {-Repeatedly damaged by } \\
\text { waves } \\
\text {-Failed during overtopping }\end{array}$ & $\begin{array}{l}\text {-Minor sand settling - Significant washout along edges and toe } \\
\text {-Toe damage during large waves or overtopping } \\
-10 \% \text { of structure broken }\end{array}$ \\
\hline Material Hazard & None & None \\
\hline $\begin{array}{l}\text { Repairs } \\
\text { Minor (M) Not Threatened Failure } \\
\text { Concern (FC) Structural Integrity }\end{array}$ & $\begin{array}{l}\text { FC } \\
\text { Add and Restack } \\
\text { Sandbags }\end{array}$ & M Add Sand \\
\hline Reusability (\%) & 0 - All Disposed & 90 \\
\hline
\end{tabular}

Table 2. Test results of sandbag and RDFW levee [1]. 


\begin{tabular}{|c|c|c|}
\hline \multicolumn{3}{|l|}{ Laboratory Test Summary } \\
\hline Item & Portadam & Hesco Bastion \\
\hline $\begin{array}{l}\text { ROW used }(m) \\
\text { Restricted by the facility size only }\end{array}$ & $n / a$ & $n / a$ \\
\hline Footprint Width (m) & 1.8 (frame) & 0.9 \\
\hline Apron Width (m) & 5.2 & $\mathrm{n} / \mathrm{a}$ \\
\hline \multicolumn{3}{|l|}{ Structure Length $(\mathrm{m})$} \\
\hline Center-line Length (m) & 20.9 & 21.8 \\
\hline \multicolumn{3}{|l|}{ Ease of Construction } \\
\hline Time (hr) & 4.8 & 3.5 \\
\hline Effort (man-hours) & 24.4 & 20.8 \\
\hline Manpower (no. men) & 5 to 6 & 6 \\
\hline Equipment & Ratchet and Socket Shovels & $\begin{array}{l}\text { Shovels } \\
916 \text { Cat }^{\oplus} \text { Front End Loader }\end{array}$ \\
\hline Sand Fill $\left(\mathrm{M}^{3}\right)$ & 250 sandbags & 19.1 \\
\hline Durability & \multicolumn{2}{|c|}{$\begin{array}{l}\text { All products stayed in the laboratory during construction and testing with no direct } \\
\text { sunlight and subjected only to the ambient temperature of the steel building. No } \\
\text { deterioration was noted. }\end{array}$} \\
\hline Varying Terrain & \multicolumn{2}{|c|}{$\begin{array}{l}\text { The laboratory test products were all built on a flat surface (finished concrete floor) } \\
\text { along the entire length of the structures. }\end{array}$} \\
\hline \multicolumn{3}{|l|}{ Ease of Removal } \\
\hline Time (hr) & 1.1 & 2.7 \\
\hline Effort (man-hours) & 4.4 & 13.4 \\
\hline Manpower (no. men) & 4 & 5 \\
\hline Equipment & $\begin{array}{l}\text { Ratchet and Socket Banding } \\
\text { Tool Forklift }\end{array}$ & $\begin{array}{l}\text { Shovels Brooms } \\
\text { Pin Removal Bar } 916 \mathrm{Cat}^{\oplus} \text { Front-end Loader }\end{array}$ \\
\hline Seepage-Hydrostatic Head Test & \multicolumn{2}{|c|}{ Seepage (liter per minute per meter of Structure) } \\
\hline $0.3 \mathrm{M}$ water elevation & 1.180 & 4.844 \\
\hline $0.6 \mathrm{M}$ water elevation & 1.677 & 11.61 \\
\hline 90 and 95 percent structure height & 1.739 & 22.48 (Retest the improved unit: 1.24 ) \\
\hline $\begin{array}{l}\text { Seepage - Dynamic Tests } 66 \text { percent Structure } \\
\text { height water elevation }\end{array}$ & \multicolumn{2}{|c|}{ Seepage (liter per minute per meter of Structure) } \\
\hline $5 \mathrm{~cm}$ wave height & 1.080 & 10.184 \\
\hline $17.8 \mathrm{~cm}$ wave height & 1.118 & 9.625 \\
\hline $27.9 \mathrm{~cm}$ wave height & 4.471 & 12.171 \\
\hline $\begin{array}{l}\text { Seepage - Dynamic Tests } 80 \text { percent Structure } \\
\text { height water elevation }\end{array}$ & \multicolumn{2}{|c|}{ Seepage (Liter per Minute per Meter of Structure) } \\
\hline $5 \mathrm{~cm}$ wave height & 1.540 & 12.916 \\
\hline $17.8 \mathrm{~cm}$ wave height & 133.14 & 13.289 \\
\hline $27.9 \mathrm{~cm}$ wave height & 253.73 & 338.997 \\
\hline \multirow[t]{2}{*}{ Overtopping } & \multicolumn{2}{|c|}{ Maximum Flow Over Structure + Seepage $\left(\mathrm{M}^{3} /\right.$ Minute $)$} \\
\hline & $\begin{array}{l}\text { Undulating elevation along } \\
\text { structure } \\
20.85\end{array}$ & $\begin{array}{l}\sim \text { Constant elevation along structure } \\
9.48\end{array}$ \\
\hline Damage - Overtopping & No damage Tested 1 hour & No damage Tested 1 hour \\
\hline Damage - Log Impact & Vinyl Tarp Puncture & No Damage \\
\hline $\begin{array}{l}\text { Structural Damage } \\
\text { During Installation, Testing, and Removal }\end{array}$ & $\begin{array}{l}\text {-Impermeable liner torn during } \\
\text { debris impact }\end{array}$ & $\begin{array}{l}\text {-Minor sand settling } \& \text { washout } \\
\text {-Some wire bending during debris impact }\end{array}$ \\
\hline Material Hazard & None & None \\
\hline $\begin{array}{l}\text { Repairs } \\
\text { Minor (M) Not Threatened Failure Concern (FC) } \\
\text { Structural Integrity }\end{array}$ & $\begin{array}{l}\text { M } \\
\text { Raise Liner bags }\end{array}$ & $\begin{array}{l}\text { M } \\
\text { Add Sandbags Place cover over the top }\end{array}$ \\
\hline Reusability (\%) & $>99$ & $>99$ \\
\hline
\end{tabular}

Table 3. Test results of Portadam and Hesco Bastion levee [1]. 